\title{
PENERAPAN PERYATAAN STANDAR AKUNTANSI KEUANGAN NOMOR 46 TENTANG AKUNTANSI PAJAK PENGHASILAN DAN UNDANG-UNDANG NOMOR 36 TAHUN 2008 TENTANG PAJAK PENGHASILAN ATAS PAJAK PENGHASILAN BADAN PADA PT.MEGA JASAKELOLA
}

\author{
Ray Marcel Letlora \\ Jantje.J. Tinangon \\ Lintje Kalangi \\ Fakultas Ekonomi dan Bisnis Jurusan Akuntansi \\ Universitas Sam Ratulangi Manado \\ email: Raymarcel07@Gmail.com
}

\begin{abstract}
ABSTRAK
Penerapan PSAK Nomor 46 tentang Akuntansi Pajak Penghasilan diharapkan dapat menjembatani antara peraturan perpajakan dengan ketentuan akuntansi.. Tujuan penelitian ini adalah untuk mengetahui penerapan PSAK No.46 dan Undang-Undang Nomor 36 Tahun 2008 atas pajak penghasilan badan pada PT.Mega Jasa Pengelola. Metode analisis yang digunakan adalah analisa deskriptif,. Hasil penelitian Penerapan PSAK No. 46 atas pajak penghasilan badan pada PT.Mega Jasakengelola telah diterapkan sesaui terutama mengenai pajak tangguhan, laba fiskal dan hutang pajak kini. Penerapan Undang-Undang Nomor 36 tahun 2008 atas pajak penghasilan pada PT.Mega Jasa Pengelola sudah sesuai peraturan Perpajakan yang ada. PT.Mega Jasakelola telah melaksanakan pelaporan Pajak Penghasilan pada SPT Tahunan, sesuai dengan ketentuan hal ini dibuktikan dengan dilakukannya koreksi positif atas biaya yang non taxable.
\end{abstract}

Kata Kunci : Penerapan Peryataan Standar Akuntansi Keuangan Nomor 46 , Undang-undang Nomor 36 Tahun 2008,Pajak Penghasilan Badan

\begin{abstract}
The application of PSAKNo. 46, Accounting for Income Taxes expected to bridge between accounting and tax laws with provisions. The purpose of this study is to investigate the application of PSAK No. 46 and Act No. 36 of 2008 on corporate income tax on PT.mega Jasakelola. The analytical method used is descriptive analysis. The application of PSAK No.46 of research results . 46 top corporate income tax has been applied on PT.Mega Jasakelola especially regarding deferred tax, taxable income and tax payable now. Implementation of Act No. 36 of 2008 on income tax on business services is appropriate PT Mega Jasakelola Taxation existing regulations. PT.Mega Jasakelola has implemented reporting income tax on their annual tax return, in accordance with the provisions of this is evidenced by the positive correction done at the expense of the non-taxable.
\end{abstract}

Keywords : Application of statement of Financial Accounting Standards No. 46, act No. 36 of 2008 , Corporate Income Tax 


\section{PENDAHULUAN}

\section{Latar Belakang}

Pemerintah telah mengeluarkan Undang-Undang Republik Indonesia nomor 36 Tahun 2008 tentang pajak penghasilan dengan menerapkan sistem self assessment sebagai sistem pemungutan pajak dimana wajib pajak diwajibkan mendaftar, menghitung, membayar, dan melaporkan sendiri jumlah pajak yang terhutang.

Penerapan Pernyataan Standar Akuntansi Keuangan (PSAK) Nomor 46 tentang Akuntansi Pajak Penghasilan diharapkan dapat dijembatani antara peraturan perpajakan dengan ketentuan akuntansi. Pernyataan Standar Akuntansi Keuangan (PSAK) Nomor 46 mengatur pengakuan, pengukuran,penyajian dan pengungkapan pajak penghasilan entitas.

Pajak penghasilan merupakan salah satu pajak langsung yang dipungut oleh pemerintah pusat atau merupakan pajak negara. Sebagai pajak langsung maka beban pajak tersebut menjadi tanggungan wajib pajak yang bersangkutan dalam arti beban pajak tersebut tidak bisa dilimpahkan kepada pihak lain dengan cara memasukkan beban pajak tersebut kepada kalkulasi harga jual. Yang menjadi objek pajak penghasilan adalah orang pribadi atau badan. Yang terkait sebagai badan antara lain : PT, CV, BUMN, BUMD, BUMS, Firma koperasi, yayasan, serta bentuk usaha tetap.

PT. Mega Jasakelola adalah merupakan anak perusahaan dari PT. Megasurya Nusalestari yang bergerak di bidang pengelolaan kawasan Mega Mas. PT. Mega Jasakelola memiliki kaitan yang sangat erat dengan Pajak Penghasilan, karena PT. Mega Jasakelola adalah merupakan Pengusaha Kena Pajak, yang telah dikukuhkan sebagai Pengusaha Kena Pajak sejak 26 September 2002 dengan Nomor NPPKP 020200978821000.

\section{Tujuan Penelitian}

Tujuan penelitian ini untuk mengetahui penerapan PSAK no.46 dan Undang-undang no 36 tahun 2008 pada PT.Mega Jasakelola sesuai dengan aturan pemerintah.

\section{TINJAUAN PUSTAKA}

\section{Konsep Akuansi Perpajakan}

Akuntansi perpajakan adalah akuntansi yang dalam penerapannya menggunakan perhitungan perpajakan dan mengacu pada peraturan dan perundang-undang perpajakan beserta pelaksanaanya disamping Prinsip dan Standar Akuntansi Keuangan (SAK). (Lubis, 2010:31).

Akuntansi Perpajakan adalah Suatu seni dalam mencatat, menggolongkan, mengihtisarkan serta menafsirkan transaksi-transaksi finansial yang dilakukan oleh perusahaan dan bertujuan untuk menentukan jumlah penghasilan kena pajak (penghasilan yang digunakan sebagai dasar penetapan beban dan pajak penghasilan yang terutang) yang diperoleh atau diterima dalam suatu tahun pajak untuk dipakai sebagai dasar penetapan beban dan/atau pajak penghasilan yang terutang oleh perusahaan sebagai wajib pajak. (Dhanny R Cysco:kamus akuntansi).

\section{Konsep Pernyataan Standar Akuntansi Keuangan No.46}

\section{Tujuan Peryataan Standar Akuntansi Keuangan No. 46}

tujuan PSAK No.46 tahun 2010 adalah sebagai berikut:

- Mengatur perlakuan akuntansi untuk pajak penghasilan

- Bagaimana mempertanggung jawabkan konsekuensi pajak pada periode berjalan dan mendatang

- Pemulihan (penyelesaian) jumlah tercatat aset (liabilitas) di masa depan yang diakui pada laporan posisi keuangan entitas.

- Transaksi-transaksi dan kejadian-kejadian lain pada periode kini yang diakui pada laporan keuangan entitas.

- Pernyataan ini juga mengatur pengakuan aktiva pajak 
- tangguhan yang berasal dari sisa rugi yang dapat dikompensasi ke tahun berikut.

- Perbedaan pengaturan dengan IAS 12 : pengaturan pajak final, SKP, penambahan kesesuaian dengan peraturan perpajakan untuk definisi aset pajak tangguhan.

\section{Pencatatan dan Penyajiannya}

Pengakuan aset dan kewajiban pajak tangguhan dilakukan terhadap rugi fiskal yang masih dapat dikompensasikan dan beda waktu antara laporan keuangan komersial dengan laporan keuangan fiskal yang dikenakan pajak, dikalikan dengan tarif pajak yang berlaku, tarif maksimum PPh $30 \%$.Jurnal untuk mencatat timbulnya asset pajak tangguhan adalah

\begin{tabular}{|c|c|c|}
\hline \multicolumn{1}{|c|}{ Keterangan } & Debit & Kredit \\
\hline $\begin{array}{l}\text { Aset pajak tangguhan } \\
\text { Pendapatan pajak tangguhan }\end{array}$ & $\mathrm{Xxxx}$ & $\mathrm{Xxx}$ \\
\hline
\end{tabular}

jurnal untuk mencatat timbulnya kewajiban pajak tangguhan adalah

\begin{tabular}{|c|c|c|}
\hline \multicolumn{1}{|c|}{ Keterangan } & Debit & Kredit \\
\hline $\begin{array}{c}\text { Beban pajak tangguhan } \\
\text { Kewajiban pajak tangguhan }\end{array}$ & $\mathrm{Xxxx}$ & $\mathrm{xxx}$ \\
\hline
\end{tabular}

Penyajian pajak tangguhan:

1.Aset pajak dan kewajiban pajak harus disajikan terpisah dari aset dan kewajiban lainnya dalam neraca.

2.Aset dan kewajiban pajak tangguhan harus dibedakan dari aset pajak kini (tax receivable/prepaid tax) dan kewajiban pajak kini (tax payable).

3.Aset atau kewajiban pajak tangguhan tidak boleh disajikan sebagai aset atau kewajiban lancar.

4.Aset pajak kini harus dikompensasikan (offset) dengan kewajiban pajak kini dan iumlah netonya disajikan dalam neraca.

5.Beban (penghasilan) pajak yang berhubungan dengan laba atau rugi dari aktivitas normal harus disajikan tersendiri pada laporan laba rugi.

6.Aset pajak tangguhan disajikan terpisah dengan akun tagihan restitusi PPh dan kewajiban tangguhan juga disajikan terpisah dengan utang PPh 29.

7.PPh final:

A. Apabila nilai tercatat aset atau kewajiban yang berhubungan dengan $\mathrm{PPh}$ final berbeda dari Dasar Pengenaan Pajaknya, maka perbedaan tersebut tidak boleh diakui sebagai aset atau kewajiban pajak tangguhan.

B. Atas penghasilan yang telah dikenakan PPh final, beban pajak diakui proporsional dengan jumlah pendapatan menurut akuntansi yang diakui pada periode berjalan.

C. Selisih antara jumlah PPh final yang terutang dengan jumlah yang dibebankan sebagai pajak kini pada perhitungan laba rugi diakui sebagai pajak Dibayar di Muka dan Utang pajak. 
D. Akun PPh final dibayar di muka harus disajikan terpisah dari PPh final yang masih harus dibayar.

8.Perlakuan akuntansi untuk hal khusus:

A. Jumlah tambahan pokok dan denda pajak yang ditetapkan dalam Surat Ketetapan pajak harus dibebankan sebagai pendapatan atau beban lain-lain pada Laporan Laba Rugi periode berjalan.

B. Apabila diajukan keberatan dan atau banding, pembebanannya ditangguhkan.

C. Apabila terdapat kesalahan mendasar, perlakuan akuntansinya mengacu pada PSAK 25 tentang Laba atau Rugi Bersih untuk periode berjalan, kesalahan mendasar, dan perubahan kebijakan akuntansi.

\section{Konsep Undang-Undang Pajak Penghasilan No 36 tahun 2008}

Menurut undang-undang pajak penghasilan pasal 4 ayat 1 penghasilan merupakan tambahan kemampuan ekonomis yang diterima atau diperoleh Wajib Pajak merupakan ukuran terbaik mengenai kemampuan Wajib Pajak tersebut untuk ikut bersama-sama memikul biaya yang diperlukan pemerintah untuk kegiatan rutin dan pembangunan.

Dilihat dari mengalirnya tambahan kemampuan ekonomis kepada Wajib Pajak, penghasilan dapat dikelompokkan menjadi :

i. penghasilan dari pekerjaan dalam hubungan kerja dan pekerjaan bebas seperti gaji, honorarium, penghasilan dari praktek dokter, notaris, aktuaris, akuntan, pengacara, dan sebagainya;

ii. penghasilan dari usaha dan kegiatan;

iii. penghasilan dari modal, yang berupa harta gerak ataupun harta tak gerak, seperti bunga, dividen, royalti, sewa, dan keuntungan penjualan harta atau hak yang tidak dipergunakan untuk usaha; dan

iv. penghasilan lain-lain, seperti pembebasan utang dan hadiah.

Dilihat dari penggunaannya, penghasilan dapat dipakai untuk konsumsi dan dapat pula ditabung untuk menambah kekayaan Wajib Pajak. pajak penghasilan digolongkan menjadi dua bagian antara lain pajak migas dan pajak non migas .pajak migas adalah pajak penghasilan yang diperoleh dari pajak minyak bumi dan gas alam .sedangkan pajak non migas antara lain :

a. Pajak penghasilan pasal 21 merupakan pemotongan pajak atas penghasilan sehubungan dengan pekerjaan, jasa, atau kegiatan dengan nama dan dalam bentuk apa pun yang diterima atau diperoleh wajib pajak orang pribadi dalam negeri wajib dilakukan .

Subjek pajak PPh pasal 21 adalah :

1. Pegawai

2. Penerima pensiun

3. Penerima honorarium

4. Penerima upah

5. Orang pribadi lainnya yang menerima / memperoleh penghasilan sehubungan dengan pekerjaan, jasa, dan kegiatan dari pemotong pajak.

b. Pajak penghasilan pasal 22 merupakan pajak yang dipungut oleh bendaharawan dari pemerintah pusat ataupun daerah,instansi,atau lembaga pemerintah dan lembaga-lembaga Negara lainnya yang berkenaan atas penyerahan barang,dan badan-badan tertentu baik badan 
pemerintah maupun swasta berkenaan dengan kegiatan di bidang impor atau kegiatan usaha di bidang lain.

Tarif PPh pasal 22 atas penjualan instansi pemerintah :

$\mathrm{PPh}$ pasal 22 bendaharawan $=1,5 \% \mathrm{x}$ nilai penjualan

Tarif PPh pasal 22 atas import :

1. Bila importir memiliki API (Angka Pengenal Impor)

$\mathrm{PPh}$ pasal 22 impor $=2,5 \% \mathrm{x}$ nilai import

2. Bila importir tidak memiliki API

$\mathrm{PPh}$ pasal 22 impor $=7,5 \% \mathrm{x}$ nilai import

c. Pajak penghasilan pasal 23 merupakan pajak yang dipotong atas penghasilan yang diperoleh atau diterima atas penghasilan wajib pajak dalam negeri dalam bentuk usaha tetap yang berdasarkan dari modal, penyerahan jasa,atau penyelengaraan kegiatan selain yang telah dipotong pajak penghasilan pph 21,yang dibayarkan atau terutang oleh badan pemerintah atau subjek pajak dalam negeri,penyelengara kegiatan,bentuk usaha tetap atau perwakilan perusahaan luar negeri lainnya.

Tarif PPh 23:

1. Deviden, royalti, bunga, hadiah penghargaan

$\mathrm{PPh}$ pasal $23=15 \% \mathrm{x}$ penghasilan bruto

2. Sewa dan jasa

$\mathrm{PPh}$ pasal $23=2 \% \times$ penghasilan bruto

d. Pajak panghasilan pasal 24 merupakan pajak yang terutang atau yang dibayarkan di luar negeri atas penghasilan yang diperoleh atau diterima dari luar negeri yang boleh dikreditkan terhadap pajak penghasilan yang terutang terhadap seluruh penghasilan wajib pajak dalam negeri .

e. Pajak penghasilan pasal 25 merupakan pajak yang diangsurkan dan harus dibayar wajib pajak untuk setiap bulan dalam tahun pajak berjalan . pajak penghasilan pasal 25 bisa di kreditkan dengan seluruh penghasilan wajib pajak pada akhir tahun dalam surat pemberitahuan tahunan pajak penghasilan sedangkan pajak penghasian pasal 29 merupakan pajak yang masih harus dibayar atas kekurangan pembayaran pajak pada akhir tahun pajak .

f. Pajak penghasilan pasal 26 merupakan pajak yang dikenakan oleh penghasilan yang diterima oleh wajib pajak luar negeri dari Indonesia,selain penghasilan yang diperoleh melalui bentuk usaha tetap di Indonesia 


\section{Penelitian Terdahulu}

Tabel 1. Matriks Perbandingan Penelitian ini dengan penelitian terdahulu

\begin{tabular}{|c|c|c|c|c|c|c|}
\hline No & Nama/Tahun & Judul & $\begin{array}{c}\text { Metode } \\
\text { Penelitian } \\
\end{array}$ & Hasil Penelitian & Persamaan & Perbedaan \\
\hline 1 & $\begin{array}{l}\text { Windy Namwi } \\
\text { Ansyur/2012 }\end{array}$ & $\begin{array}{l}\text { Analisis } \\
\text { Penerarapan } \\
\text { PSAK No } 46 \\
\text { pada Laporan } \\
\text { Keuangan } \\
\text { pada PT Prima } \\
\text { Karya } \\
\text { Manunggal }\end{array}$ & $\begin{array}{l}\text { Analisis } \\
\text { deskriptif }\end{array}$ & $\begin{array}{l}\text { Perusahaan telah } \\
\text { menerapkan } \\
\text { akuntansi pajak } \\
\text { penghasilan pada } \\
\text { laporan } \\
\text { keuangannya, } \\
\text { namun belum } \\
\text { sepenuhnya } \\
\text { mengakui adanya } \\
\text { konsekuensi atas } \\
\text { pajak di masa } \\
\text { yang akan datang } \\
\text { berupa perubahan } \\
\text { kewajiban jangka } \\
\text { panjang menjadi } \\
\text { kewajiban jangka } \\
\text { pendek }\end{array}$ & \begin{tabular}{l}
\multicolumn{3}{l}{ Penerarapan } \\
PSAK No 46 \\
tentang pajak \\
penghasilan
\end{tabular} & $\begin{array}{l}\text { Penelitian } \\
\text { terdahulu tidak } \\
\text { meneliti } \\
\text { Undang-undang } \\
\text { Nomor } 36 \text { Tahun } \\
2008\end{array}$ \\
\hline 2 & $\begin{array}{l}\text { Wulan } \\
\text { Puspitasari } \\
\text { (2011) }\end{array}$ & $\begin{array}{l}\text { Dampak } \\
\text { Penerapan } \\
\text { Undang- } \\
\text { Undang No } 36 \\
\text { Tahun 2008 } \\
\text { Tentang Pajak } \\
\text { penghasilan } \\
\text { Terhadap } \\
\text { Jumlah Wajib } \\
\text { Pajak dan } \\
\text { penerimaan } \\
\text { Pajak }\end{array}$ & $\begin{array}{l}\text { Analisis regresi } \\
\text { berganda }\end{array}$ & $\begin{array}{l}\text { Terdapat } \\
\text { perbedaan yang } \\
\text { signifikan } \\
\text { terhadap wajib } \\
\text { pajak dan } \\
\text { penerimaan pajak } \\
\text { sebelum dan } \\
\text { sesudah undang- } \\
\text { undang nomor } 36 \\
\text { tahun 2008 }\end{array}$ & \begin{tabular}{l}
\multicolumn{3}{l}{ Penerapan } \\
Undang-Undang \\
No $36 \quad$ Tahun \\
$2008 \quad$ tentang \\
pajak penghasilan
\end{tabular} & $\begin{array}{l}\text { penelitian } \\
\text { sebelumnya } \\
\text { menggunakan } \\
\text { analisis regresi } \\
\text { berganda } \\
\text { sedangkan } \\
\text { penulis } \\
\text { mengunakan } \\
\text { analisis } \\
\text { deskriptif }\end{array}$ \\
\hline
\end{tabular}

\section{METODE PENELITIAN}

\section{Jenis Penelitian}

Jenis penelitian ini adalah deskriptif untuk memberikan gambaran cara sistematis dan akurat mengenai fakta, sifat dari hubungan antar fenomena yang diteliti pada suatu perusahaan.

\section{Tempat dan Waktu Penelitian}

Tempat Penelitian adalah PT. Mega Jasakelola Manado. Waktu penelitian dilakukan pada bulan oktober sampai november.

\section{Prosedur Penelitian}

Pelaksanaan penelitian dapat diuraikan sebagai berikut.

1. Mengajukan Permohonan Penelitian Pada tahap ini dimulai dengan memasukan surat permohonan penelitian yang sudah dibuat peneliti dengan persetujuan fakultas untuk melakukan penelitian pada objek tersebut.

2. Pengumpulan DataTahap ini dimulai dari mengumpulkan data pendukung penelitan yaitu stuktur organisasi,PPh pasal 21,PPh pasal 22,PPh pasal 23,PPh pasal 25,PPh pasal 29,laporan keuangan,laporan laba rugi 
3. Analisa Data Penelitian Pada tahap ini dilakukan analisa pada data yang ada sesuai dengan judul penelitian untuk melengkapi dan menentukan hasil penelitian yang akan diambil.

4. Kesimpulan dan Saran Pada tahap ini merupakan tahapan akhir dari penelitian dengan menarik kesimpulan dari hasil penelitian mengenai Penerapan PSAK nomor 46 dan Undang undang nomor 36 tahun 2008 pada PT.Mega Jasakelolah

\section{Metode Pengumpulan Data}

\section{Jenis Data}

Jenis data dalam penelitian ini menurut Kuncoro (2003: 124). ada 2 jenis data, yaitu :

1. Data kuantitatif ,adalah data yang disajikan dan diukur dalam suatu skala numerik atau dalam angka-angka.Dalam penelitian ini data kuantitatif yang di butuhkan adalah hasil jumlah pph terutang dan laporan keuangan pada PT.Mega jasakelola

2. Data kualitatif ,adalah data yang bersifat deskriptif atau berbentuk uraian atau penjelasan serta tidak dapat diukur dalam skala numerik.Dalam penelitian ini data kualitatif yang di butuhkan adalah yang merupakan gambaran umum perusahaan tersebut dan stuktur organisasi.

\section{Sumber Data}

Sumber data menurut Kuncoro (2003 : 127) dibedakan menjadi dua jenis yaitu

1. Data primer adalah data yang diperoleh langsung dari tempat penelitian melalui metode pengamatan dan wawancara langsung kepada pihak yang terkait dengan data-data yang ada.

2. Data sekunder adalah data yang sudah ada, diperoleh secara lisan maupun tulisan menyangkut dengan objek penelitian .

\section{Metode Pengumpulan Data}

1. Penelitian Lapangan

a) Wawancara, yaitu melakukan kegiatan tanya jawab dengan pimpinan dan karyawan perusahaan tentang hal-hal yang berhubungan dengan penelitian ini.

b) Observasi, yaitu melakukan pengamatan langsung terhadap objek penelitian, guna mendapatkan data-data yang dibutuhkan.

\section{Metode Penelitian Kepustakaan (Library Research Method)}

Yaitu pengambilan data dari berbagai literatur-literatur dengan masalah yang dihadapi guna mendapatkan landasan teori, tinjauan pustaka, dan analisis yang sesuai dalam memecahkan masalah tersebut.

3. Mengakses Website dan Situs-situs terkait Website atau situs-situs yang menyediakan informasi yang berkaitan dengan masalah tersebut

\section{Metode Analisis}

Metode analisis yang digunakan dalam penelitian ini adalah analisis deskripsi. yaitu suatu metode pembahasan masalah yang sifatnya menguraikan, menggambarkan, suatu data atau keadaan serta melukiskan dan menerangkan suatu keadaan sedemikian rupa sehingga dapatlah ditarik suatu kesimpulan. mengetahui penerapan PSAK No. 46 dan Undang-Undang Nomor 36 tahun 2008 atas pajak penghasilan pada PT. Mega Jasakelola sebagai Perusahaan jasa Persewaan Ruangan dan Pengelolaan Kawasan Mega Mas dengan peraturan Undang-undang Perpajakan yang ada. 


\section{HASIL PENELITIAN DAN PEMBAHASAN}

\section{Gambaran Umum Objek Penelitian}

PT. Megasurya Nusalestari didirikan pada tanggal 29 Desember 1994 dengan Akta Notaris No 85 yang dibuat dihadapan Notaris Sri Hartini Widjaja, SH, di Ujung Pandang Sulawesi Selatan. Namun Akte pendirian tersebut telah mengalami perubahan yakni melalui Akta Risalah Rapat Pemegang Saham No. 29 yang dibuat pada tanggal 26 Februari 1999 dihadapan Notaris yang sama. Sesuai Akta Notaris tersebut, maksud dan tujuan PT. Megasurya Nusalestari adalah untuk bergerak dalam bidang usaha Pembangunan Perumahan, Property dan Developer, kontraktor, Perdagangan umum, Pertanian dan Perkebunan, industri jasa, dan lain sebagainya.

bidang Usaha dan aktivitas usaha dari PT. Mega Jasakelola adalah :

a. Jasa Persewaan Ruangan

Jasa persewaan Ruangan yang dilakukan tersebut meliputi:

(1) Jasa Persewaan Ruangan Kios

(2) Jasa Persewaan Ruangan Marquis

(3) Jasa Persewaan Ruangan ATM Galery

Jasa Persewaan Lahan

b. Jasa Perparkiran

c. Jasa Keamanan dan Kebersihan

d. Jasa Rekreasi Laut

e. Jasa Penyediaan Listrik Kawasan

\section{Hasil Penelitian}

\section{PT Mega Jasakelola}

Neraca

Per 31 Desember 2012 dan 2011

\begin{tabular}{|c|c|c|c|}
\hline Keterangan & 2012 (Rp) & 2011 (Rp) & Ket \\
\hline AKTIVA & & & \\
\hline Aktiva lancar & & & \\
\hline Kas & 675.158 .290 & 611.600 .062 & \\
\hline Bank & 1.948.505.267 & 2.336.642.129 & \\
\hline Deposito & 1.425 .000 .000 & 379.700 .000 & \\
\hline Piutang dagang & 45.404.767.820 & 35.514 .096 .442 & \\
\hline Piutang karyawan & 318.110 .714 & 428.125 .864 & \\
\hline Cadangan Kerugian piutang & $(5.348 .300 .126)$ & $(4.793 .297 .385)$ & (2) \\
\hline Persediaan & 5.876.754.868 & 8.797 .164 .320 & \\
\hline Pekerjaan dalam pelaksanaan & 5.949 .5000 & - & \\
\hline Pembayaran dimuka & 2.213.017.296 & 1.618 .532 .212 & \\
\hline Biaya dibayar dimuka & 548.239 .384 & 1.022.667.194 & \\
\hline Pajak dibayar dimuka & 3.614.810.904 & 1.604.388.665 & \\
\hline Jumlah aktiva lancer & 56.682 .013 .920 & 47.519.519.505 & \\
\hline Investasi jangka panjang & & & \\
\hline Penyusutan modal & 1.201 .000 .000 & 1.200 .000 .000 & \\
\hline Jumlah investasi jangka panjang & 1.201 .000 .000 & 1.200 .000 .000 & \\
\hline Aktiva tetap & & & \\
\hline Bangunan & 1.376 .705 .654 & 1.512.279.898 & \\
\hline Harga perolehan bangunan & 2.710 .803 .674 & 270.803 .674 & \\
\hline Akum Peny bangunan & 1.334 .094 .020 & 1.198.523.776 & \\
\hline Mesin dan peralatan & 2.448.549.806 & 2.658 .665 .114 & \\
\hline Hp mesin dan peralatan & 5.403 .944 .008 & 5.236 .149 .008 & \\
\hline Akum peny mesin dan peralatan & 2.955.394.201 & 2.577 .683 .893 & (3) \\
\hline
\end{tabular}




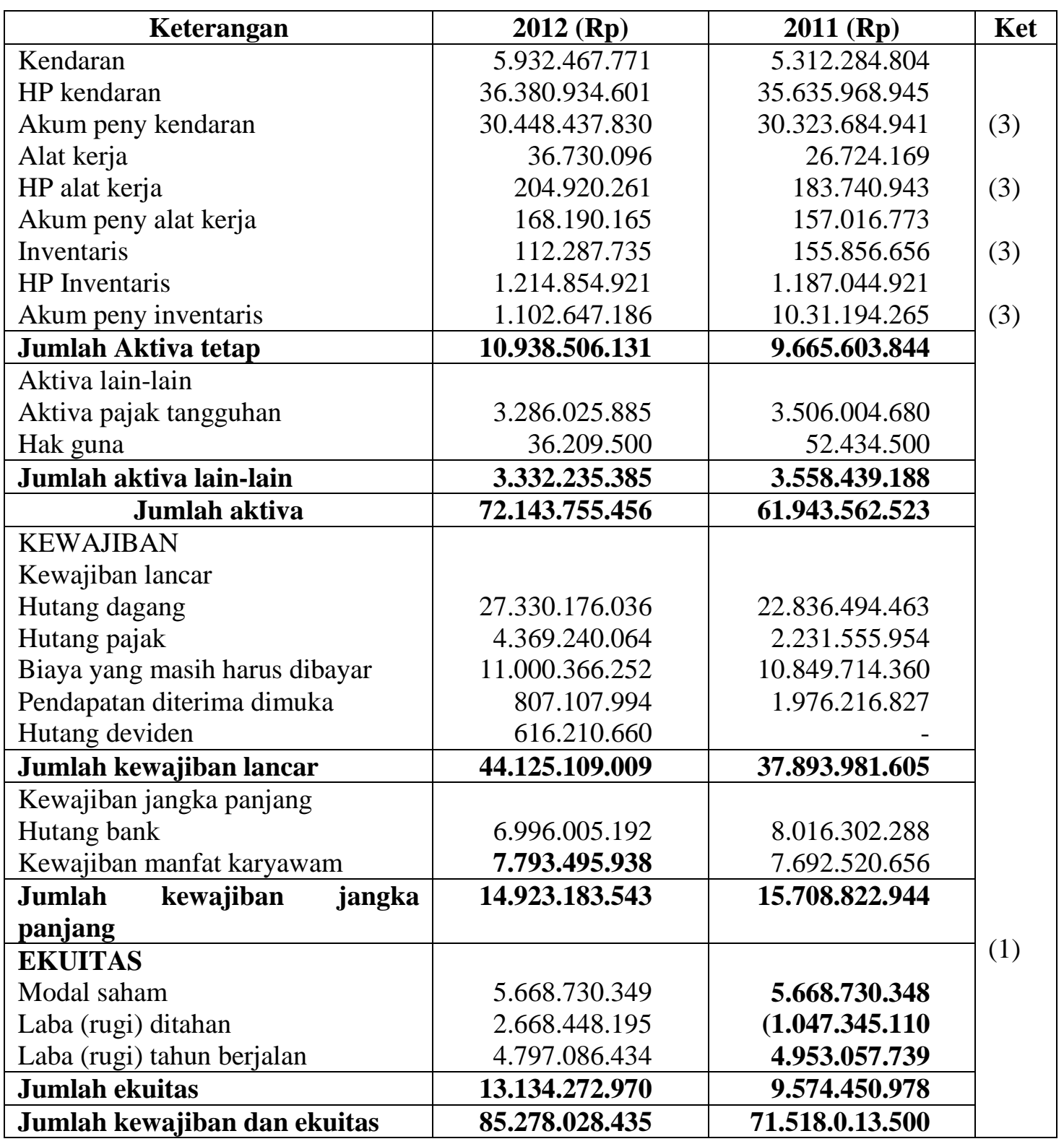

Sumber : PT. Mega Jasakelola, 2013

Berdasarkan neraca PT Mega Jasakelola dapat di ketahui bahwa :

1. Kewajiban manfaat karyawan adalah saldo pencadangan untuk imbalan paska kerja karyawan yang dihitung sebesar 18 kali penghasilan karyawan sebagai pesangon, termasuk juga penghargaan yang dihitung berdasarkan masa kerja karyawan. Namun bagi peraturan perpajakan yang tidak mengakui konsep konservatisme, maka imbalan paska kerja karyawan hanya akan dibebankan saat telah dibayarkan. Oleh karena itu, kewajiban ini tidak diakui oleh pajak dan menimbulkan perbedaan sementara.

2. Perusahaan mencadangkan kerugian piutang yang mungkin diperoleh perusahaan akibat tidak tertagihnya piutang. Hal ini tidak diakui oleh pajak.

3. Total beban penyusutan dihitung berdasarkan estimasi yang dilakukan perusahaan memiliki beberapa perbedaan dengan aturan perpajakan, sehingga saat rekonsiliasi fiskal terdapat selisih penyusutan yang boleh diakui perusahaan berdasarkan peraturan perpajakan.

4. Ketiga hal sebelumnya, kewajiban manfaat karyawan, cadangan kerugian piutang dan selisih pembebanan penyusutan merupakan total perbedaan sementara antara peraturan perpajakan dengan estimasi perusahaan. Total perbedaan ini kemudian dikalikan 25\% untuk tahun 2010 (setelah 2009, aktiva pajak tangguhan tidak lagi $28 \%$ dari total perbedaan).

PT. Mega Jasakelola telah menerapkan Pernyataan standar akuntansi keuangan No 46 dan undang-undang nomor 36 tahun 2008 tentang pajak penghasilan mengenai akuntansi pajak 
penghasilan. Penerapan akuntansi yang dilakukan oleh perusahaan ini dalam mengakui konsekuensi perhitungan pajak penghasilan adalah sebagai berikut:

1. Menentukan aktiva pajak tangguhan, perusahaan menentukan selisih sementara antara perhitungan yang dilakukan perusahaan dengan perhitungan yang dilakukan pihak fiskus, hal ini dilakukan dengan membandingkan neraca menurut perusahaan dengan neraca menurut peraturan perpajakan (balance sheet liability method);

2. Menghitung laba fiskal dan hutang pajak, laba fiskal didapatkan dari perhitungan koreksi fiskal yang telah perusahaan lakukan sebelumnya, dengan demikian kemudian diketahuilah utang pajak kini perusahaan;

3. Menghitung laba komersial, laba komersial dihitung setelah mengurangkan dan/atau menambahkan saldo laba tahun berjalan di neraca dengan biaya yang tidak sesuai perhitungan pajak. Setelah itu dikurangkan dengan beban pajak kini dan beban pajak tangguhan sehingga didapatkan laba komersial bersih;

PT Mega Jasakelola

Laporan Rugi Laba

Per 31 Desember 2012 dan 2011

\begin{tabular}{|c|c|c|}
\hline Keterangan & $2012(\mathrm{Rp})$ & 2011 (Rp) \\
\hline PENDAPATAN USAHA & 69.772.766.019 & 66.533.675.461 \\
\hline BEBAN USAHA & $\underline{55.112 .046 .707}$ & $\underline{55.253 .616 .982}$ \\
\hline LABA (RUUGI) KOTOR & 14.660.719.312 & 11.200 .058 .479 \\
\hline PENDAPATAN BEBAN LAIN-LAIN & & \\
\hline Pendapatan lain-lain & 6.817.707.413 & 8.517.206.005 \\
\hline Beban lain-lain & $\underline{14.738 .328 .206}$ & $\underline{14.372 .480 .104}$ \\
\hline Total pendapatan (beban ( lain-lain & 7.420.620.791 & 3.855.274.089 \\
\hline SEBELUM & & \\
\hline PENGHASILAN & 7.240.098.519 & 7.344.784.390 \\
\hline TAKSIRAN PPH BADAN & & \\
\hline Beban pajak kini tidak final & - & 446.536 .250 \\
\hline Beban pajak kini final & 4.813.328.608 & 3.128 .290 .696 \\
\hline Beban (manfaat pajak tangguhan) & 2.544 .629 .957 & $\underline{191.177 .784}$ \\
\hline LABA & 2.268 .698 .651 & 3.506 .004 .680 \\
\hline PAJAK & 4.971.399.888 & 3.838.779.710 \\
\hline
\end{tabular}

Sumber : PT. Mega Jasakelola, 2013

PT. Mega Jasakelola telah menerapkan Pernyataan standar akuntansi keuangan No 46 dan undang-undang nomor 36 tahun 2008 tentang pajak penghasilan mengenai akuntansi pajak penghasilan. Penerapan akuntansi yang dilakukan oleh perusahaan ini dalam mengakui konsekuensi perhitungan pajak penghasilan yaitu perusahaan menghitung hutang pajak yang masih harus dibayar, karena adanya uang muka PPh yang dibayar perusahaan tiap bulannya (PPh 25 masa), maka total pajak yang harus dibayarkan tidak sebesar utang pajak yang telah dihitung sebelumnya.

\section{Pembahasan}

\section{Penerapan PSAK No. 46 Atas Pajak Penghasilan pada PT.Mega Jasakelolah}

Jurnal

Beban pajak kini

Aktiva pajak kini

Rp 1.891.783.550

Rp 1.891.783.550

Berdasarkan perhitungan beban pajak kini, maka dapat diketahui hutang pajak yang masih harus dibayar oleh perusahaan dengan mengurangkannya dengan PPh 25 masa yang telah dibayar sebelumnya, sehingga:

Hutang pajak (PPh 29)

Pajak yang di bayar dimuka 2011

Hutang PPh yang masih harus dibayar
$\operatorname{Rp} 1.891 .783 .550$

Rp 1.604.288.665 -

Rp 287.494.885 
Dari pembahasan diatas dapat diketahui bahwa point-point dalam PSAK No. 46 telah diterapkan dengan benar pada PT. Mega Jasakelola terutama mengenai pajak tangguhan, laba fiskal dan hutang pajak kini.

\section{Jurnal Pencatatan Kredit Pajak :}

Piutang PPh 25 Rp 3.614.810.904

Piutang PPh Pasal 23 Sewa $\quad$ Rp 287.000.000
Kas
Rp 3.614.810.904
Pendapatan Sewa
Rp 287.000.000

- Jurnal Pencatatan Kurang Bayar :

Biaya PPh Rp 6.887.378.250
Piutang PPh 25
Rp 3.614.810.904
Piutang PPh Sewa
Rp 287.000.000
Kas
Rp 2.985.567.350

\section{- Jurnal Pencacatan Pembayaran PPh \\ Hutang PPh Rp 2.985.567.350 \\ Kas Rp 2.985.567.350}

Selain itu perusahaan juga diwajibkan untuk menghitung dan melaporkan dalam SPT PPh Tahun yang bersangkutan mengenai jumlah PPh pasal 25 tahun berikutnya diangsur setiap bulan, yaitu dengan cara pajak penghasilan yang terutang menurut SPT PPh Tahun yang bersangkutan dikurangi dengan $\mathrm{PPh}$ yang dipotong atau dipungut serta $\mathrm{PPh}$ yang dibayar dan terhutang diluar negeri yang boleh dikreditkan kemudian dibagi 12 (dua belas) bulan. Perhitungan Pajak yang harus diangsur (PPh pasal 25) PT. Mega Jasakelola adalah sebagai berikut :

Laba sebelum pajak

Pendapatan tidak teratur

Laba Dasar Perhitungan PPh pasal 29

Pajak Penghasilan Terutang :

- $25 \%$ X 17.398.513.000

Jumlah Pajak Penghasilan Terutang

Kredit Pajak

- PPh Pasal 23 atas Sewa

Jumlah Kredit Pajak'

$\mathrm{PPh}$ yang dibayar sendiri

- PPh Pasal 25

Dasar Perhitungan Angsuran per tahun

Angsuran PPh Pasal 25 per bulan

Dari pembahasan diatas dapat diketahui bahwa penerapan Undang-Undang Nomor 36 tahun 2008 atas pajak penghasilan pada PT.Mega Jasakelola sudah sesuai peraturan Perpajakan yang ada.
Rp 27.549.513.000

$\mathrm{Rp}(10.151 .000 .000)$

Rp 17.398.513.000

Rp 4.349.628.250
Rp 287.000.000

$$
\begin{aligned}
& \text { Rp }(287.000 .000) \\
& R p(3.614 .810 .904) \\
& \operatorname{Rp} \quad 447.817 .350
\end{aligned}
$$

\section{PENUTUP}

\section{Kesimpulan}

Dari uraian pembahasan yang telah dikemukakan di atas, maka diperoleh beberapa kesimpulan sebagai berikut:

1. Penerapan PSAK No. 46 atas pajak penghasilan badan pada PT.Mega Jasakelola telah sesuai dengan PSAK No. 46 terutama mengenai pajak tangguhan, laba fiskal dan hutang pajak kini.

2. Penerapan Undang-Undang Nomor 36 tahun 2008 atas pajak penghasilan pada PT.Mega Jasakelola sudah sesuai peraturan Perpajakan yang ada.

3. PT. Mega Jasakelola telah melaksanakan pelaporan Pajak Penghasilan pada Surat Pemberitahuan Tahunan, sesuai dengan ketentuan hal ini dibuktikan dengan dilakukannya koreksi positif atas biaya yang non taxable. 


\section{Saran}

Berdasarkan kesimpulan di atas maka saran yang diajukan kepada PT. Mega jasakelola adalah:

1. Dengan adanya perubahan undang-undang perpajakan yang berlaku maka selama Tahun 2008 pemerintah memberikan pengampunan pajak atau lebih dikenal dengan nama Sunset Policy, setiap perusahaan dapat memanfaatkan fasilitas yang diberikan oleh pemerintah tersebut. Akan tetapi, setelah dilakukan analisis setiap perusahaan tidak terdapat adanya pelanggaran terhadap kewajiban perpajakannya.

2. Selalu memperhatikan dan melakukan komunikasi dengan pihak Fiskus untuk mengetahui ketentuan-ketentuan baik berupa Keputusan Menteri Keuangan maupun Peraturan Pemerintah lainnya mengenai pajak penghasilan.

\section{DAFTAR PUSTAKA}

Anastasia Diana dan Lilis Setiawati, 2009, Perpajakan Indonesia Konsep,

Aplikasi

dan

Penutupan Praktis, ANDI, Yogyakarta.

Agoes, Sukrisno dan Estralita Trisnawati 2009. Pajak Penghasilan Teknik Rekonsiliasi Fiskal. Edisi Kedua. Yogyakarta. Ekonisia.

Lubis, Irsan, 2010. Akuntansi Perpajakan. LPMB/STEI. Ciledug

Mardiasmo. 2009. Perpajakan. Edisi XVI- Revisi 2009. Penerbit Andi Yogyakarta

Suandy, Erly 2011. Hukum Pajak. Edisi Pertama. Jakarta. Penerbit Salemba Empat.

Siahaan, Marihot Pahala. 2010. Hukum Pajak Elementer Konsep Dasar Perpajakan Indonesia. Yogyakarta : Graha Ilmu.

Simamora Hendry 2013. Akuntansi manajemen Edisi III. Stard Date Publiser. Jakarta

Siti, Resmi. 2007. Perpajakan Teori dan Kasus, Dua, Salemba Empat ; Jakarta.

Soemitro Rochmat. 2007. Dasar-dasar Hukum Pajak dan Pajak Pendapatan; PT. Eresco, Bandung .

Waluyo. 2011. Perpajakan Indonesia. Edisi 10. Penerbit Salemba Empat. Jakarta

Undang-Undang Nomor 16 tahun 2009 mengenai Ketentuan Umum dan Tata Cara Perpajakan 